\title{
Criteria for evaluating and selecting suppliers for maritime enterprises
}

\author{
Artem Lopatin ${ }^{1 *}$, Natalia Ishchenko $^{1}$, Olena Filimonova ${ }^{1}$, and Natalia Rudenko $^{1}$ \\ ${ }^{1}$ Petro Mohyla's Black Sea National University, 54000, Mykolaiv, Ukraine
}

\begin{abstract}
Supplier selection problem for maritime enterprises might be solved by using a combination of information processing methods. In this article we propose to use an integrated approach to problem analysis, specifically a multi-objectives analysis merged with analytical hierarchical process (AHP-method), k-meaning cluster analysis and Taboo Search as a way of sorting and clusterization of potential suppliers. The main purposes of this article are to provide academic researchers, maritime companies with an evaluation methodology of potential suppliers. In addition, it might be helpful for suppliers to evaluate themselves and direct their attention to the fields that matter the most for their customers. The article identifies supplier selection's criteria and sub-criteria that fits the most for maritime enterprises such as (a) parts and stores companies or (b) bunkers and lubricators suppliers 'selection accordingly. Also shows the way to gradate list of potential suppliers based on the compilation of their scores on certain sub-criteria and its weight for customer-company using analytical hierarchical process. In addition, suggested the combination of k-meaning cluster analysis with Taboo Search as a way to choose a group of suppliers for enterprises that prefer to work with couple suppliers.
\end{abstract}

\section{Introduction}

Picking a supplier is a difficult task for any maritime enterprise. Selection of the right supplier potentially allows a company to get the right raw materials, repairs and consumption on board, including parts, stores, bunkers and lubricators in the right quantity and at the right price at the right time. This task requires decisions based on multi-criteria qualitative and quantitative analysis of suppliers and the use of additional methods of data processing for more accurate and flexible evaluation of the supplier. In this paper we propose an option solution to this problem.

The purpose of the article is to help maritime enterprises to assess the potential of certain suppliers. For that purpose we offer a comprehensive approach to choosing a supplier. As a result of the algorithm of actions given in the article, all important qualities necessary for suppliers are selected, according to the needs of the consumer company, and the obtained data are further processed. In addition, this algorithm is interesting for suppliers because, based on it, suppliers' sales department is able to increase product sales, based on their own marketing strategy and adapt it to the results of the study. Also by this

\footnotetext{
*Corresponding author: areterik@gmail.com
} 
study we wanted to match and adopt supplier selection criteria that are used to be used in international literature with those are met in Ukrainian science journals and presented by a Ukrainian companies.

\section{Theory background and literature rewiew}

Among Ukrainian scientists in substantiating the choice of supplier the greatest attention is paid to multi-criteria hierarchical analysis, these are the articles of such scientists as Bilovodskaya O.A. [1], Voznyuk N.A., Parubets E.N. etc. [2], Romashchenko O.S. [3], Kondratyuk D.M. [4] and others. The developments of foreign scientists are broader and pay attention to more diverse methods of supplier selection: Che, Wang [5], Yu, Wong [6], Khalele, Fasanghari [7], Versaci [8], Hsu [9] and others. However, comprehensive approaches to supplier selection using a combination of methods, which allows to improve existing methodologies, as well as to adapt solutions to different specialization / size / industry / capacity of enterprises, remain insufficiently covered.

Selecting the right suppliers plays a key role in any organization, as it significantly effects on the prices of proposed services and the competitiveness of the enterprise. However, in addition to the price factor in a competitive market, quality, timeliness of delivery and other factors play an important role, which complicates the choice of suppliers.

In practice, the choice of supplier by the company depends on a number of criteria, such as the proposed price, delivery time, after-sales service, flexibility in changing orders, location and financial condition of the supplier, etc. Therefore, the choice of supplier is a multi-criteria problem, which includes the assessment of both qualitative and quantitative indicators. In order for a company to choose the best supplier, it is necessary to make a compromise between these qualitative and quantitative factors.

In addition, Ghodsypour and O'Brien [10] identified two types of solutions to the problem of choosing a supplier: 1) a single supplier; 2) several suppliers.

If the chosen strategy involves a single supplier, it means that each supplier can meet all the requirements of the consumer in terms of quantity, quality and delivery of parts/stores/lubricants etc. In this case, the consumer's management needs to make only one decision - which supplier is the best. In this case, it is advisable to use a simple multicriteria analysis and choose the supplier with the highest weighted assessment. On the other hand, if a firm plans to have several suppliers, it means that there are certain limitations in the supplier's ability to satisfy the consumer by one of the factors, or it is the costumer's principles to diversify its supplies.

\section{Supplier selection methods}

\subsection{Analytical hierarchy process}

\subsubsection{Basics of analytical hierarchy process}

The methodology of suppliers evaluation proposed by the authors provides for the gradual use of several methods, the combination of which will allow to select not only a specific single supplier, but also to evaluate and choose a certain combination of several suppliers. This might be achieved by using the following algorithm:

1) At the first stage, it is makes sense to use multi-criteria analysis by building a hierarchical model of suppliers. 
2) Further data processing using the k-method of clustering (grouping) of suppliers for primary groups and using Taboo-search to optimize this clustering.

Multi-criteria analysis involves choosing a supplier from many conflicting factors through some compromise. Thus, multi-criteria analysis helps decision makers to evaluate a number of alternatives. However, depending on market conditions and management preferences, the criteria are of different importance and require weighing them [11].

Analytical hierarchy process (AHP) was first developed in 1971-75 in the work of Saati from 1987 [12] and was further developed in many works of both foreign $[13,14]$ and Ukrainian scientists [15]. This is a fairly popular method that is used due to its simplicity, no needs of specific knowledge in that field and is quite reliable for solving complex reallife problems. AHP divides the solution of a complex problem into a hierarchical system of a number of simple solutions. A matrix of pairwise comparison of these solutions is constructed, and then the vectors of each of these solutions are compared with the general vector, which takes into account the weight of each criterion in general. The procedure of AHP can be summarized in the following 4 stages [12]:

1. Construction of a hierarchical system. It must have at least 2 or more levels, and helps to relate each decision to a certain level, each of which consists of several elements. In general, AHP divides a complex problem into three levels: the overall goal; used evaluation criteria (goals); examined alternative solutions. The criteria for evaluating the effectiveness of the decision for each level should be independent of each other and go from higher priority to lower priority criteria.

2. Pairwise comparison of criteria and alternative solutions. In this manner compares the weight of the alternative solution. The result will be a ranking scale of criteria and alternative solutions for each of the criteria, taking into account their weight.

3. Calculation of local weights of hierarchy elements. Normalized values of matrix vectors, or approximate values based on the geometric mean, are used for calculation.

4. Calculation of the total weight of alternative solutions. That means that, the weight obtained for each of the criteria for each of the alternative solutions are summed. As a result of this stage, a table with ranked alternatives will be obtained. The responsible person chooses the alternative with the highest weight value.

However, in further studies [16], as a first stages, are also identified: the definition of criteria, sub-criteria and the collection of information about the supplier.

\subsubsection{Review of supplier selection criteria}

To select the criteria by which suppliers should be evaluated, the most frequently used criteria in Ukrainian and foreign literature were analyzed $[1,3,9,16,17]$ and the specifics of maritime enterprises were taken into account. Thus, a hierarchical structure of criteria and sub-criteria for choosing a supplier is presented in Figure 1.

Costs are considered to be the most important criterion, as maritime enterprises operate in highly competitive markets, and for the consumer it is the final cost of proposed service (which directly depends on costs) that becomes the decisive factor. It is also one of the simplest criteria to calculate (and at the same time most transparent) criteria, as it is purely quantitative and most data can be obtained from open sources.

Quality is the most important factor for some industries in which -sized maritime businesses operate, as it is not possible to compete on price with large companies. In addition, the low quality of parts/stores/lubricants etc. determines the low quality of the proposed services, which is more likely will lead to some cost compensation, or discourage the consumer from further recourse to the maritime company, which increases marketing costs per costumer and so on. 


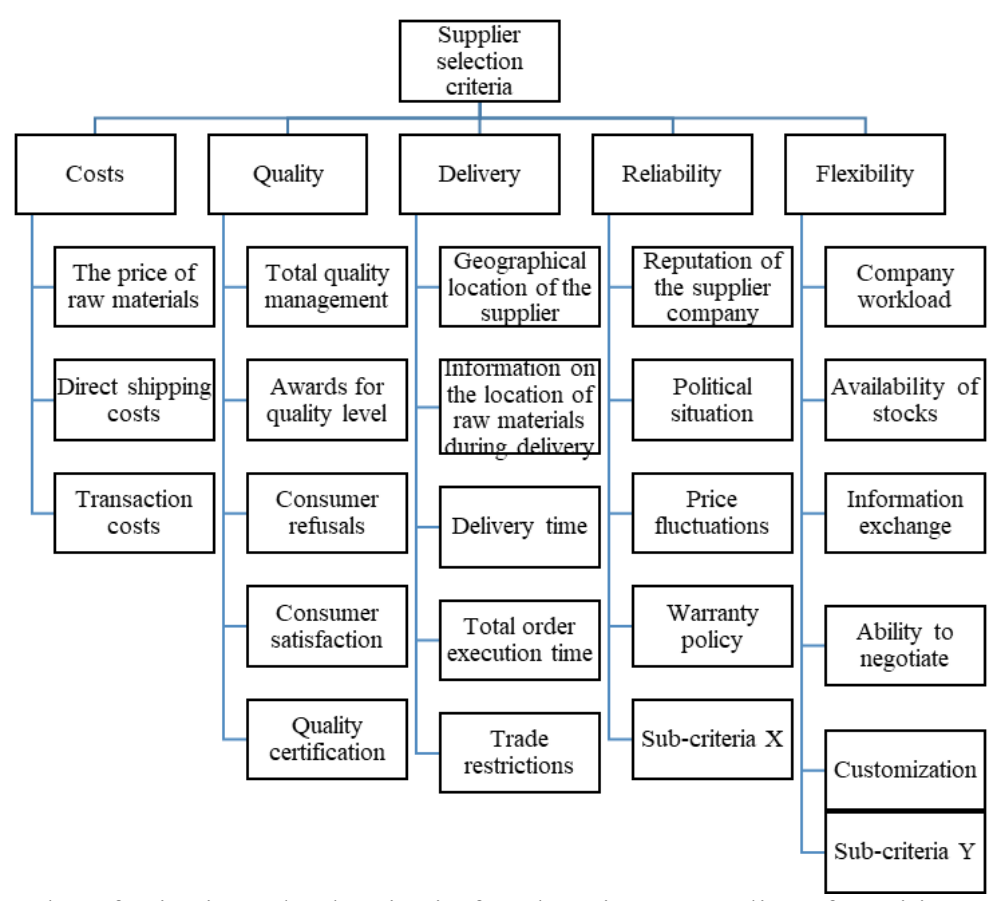

Fig. 1. Hierarchy of criteria and sub-criteria for choosing a supplier of maritime enterprise $[1,3,9,16,17]$.

This criterion is less than directly priced because it is not quantitative, however, there is some unification of supplier evaluation by comparing quality awards and the availability of appropriate certification.

The delivery criterion strongly influences the procurement strategy, especially in sectors where the product has a short life cycle. Therefore, the total execution time of the order is crucial for the business, as it affects a number of associated costs (storage, shipment) and customer satisfaction.

The criterion of trust is somewhat biased due to incomplete information and a number of evaluative judgments, in addition, it strongly depends on the responsible person. Therefore, the proposed set of sub-criteria does not include a fairly common sub-criterion of "trust", but rather relies on indirect but open data. In addition, both internal factors of the supplier company and external national factors are taken into account. Beside, that criteria include sub-criteria $X$, which might differ from one type of enterprise to another. Thus, (a) quality sample test and technique problem response or (b) integrated capability for service and delivery from other suppliers suites for (a) parts and stores suppliers 'selection or (b) bunkers and lubricators suppliers 'selection accordingly.

The criterion of supplier flexibility can be considered as a tool by which the maritime company that propose service reduces the risks and consequences of an unstable environment and short-term changes in end-consumer demand. Flexibility means the ability of a supplier company to respond to short-term changes in demand and other external obstacles, as well as the ability to adapt to new conditions. This is the most difficult factor to assess, as most of the information must be found from indirect data even before the start of collaboration with new company. Moreover, the most important thing is to trust the information provided by the supplier in that case, which entails uncertainty. Yet, if company have some experience working with a number of suppliers, company can more accurately assess the alternatives by this criterion. Similarly, to the previous criteria, that 
criterion include sub-criteria $\mathrm{Y}$, which might differ from one type of enterprise to another. Thus, (a) reachable delivery for long distance or (b) integrated capability for service and delivery from other suppliers suites for (a) parts and stores suppliers 'selection or (b) bunkers and lubricators suppliers 'selection accordingly.

In the case of the desire and ability of the maritime company to work with one parts/stores/lubricants supplier most likely it will be enough to build a hierarchical model. In this way, company can clearly assess the position of each supplier in the ranking, based on the total number of points of the integrated indicator, taking into account the personal wishes of the company's management.

In turn, if the involvement of only one supplier is not possible due to a number of related factors, it will be appropriate to further process of the data.

\subsection{Data processing}

\subsubsection{Cluster analysis}

Clustering by using k-means is one of the simplest unsupervised learning algorithms. The procedure is performed by a simple way of classifying the input data set (summarized values of evaluation points) through a certain number of pre-fixed k-clusters [26]. In Ukrainian scientific literature mostly used in a the technical field, such as energetics, computer science, fraud detection, health data etc. [19, 20, 21, 22], in economics that method is applied to the marketing task. However, there are very few articles that reveal the application of cluster analysis for the purpose of grouping and evaluation of suppliers [23], despite the fact that there are already many international sources on this field [5, 24, 25].

The basic idea is to define $\mathrm{k}$ centroids, one for each cluster. The placement of the centroids is a component to choose from, as it affects the end result. Many works indicate random placement of centroids, but if you place them as far apart as possible - this will reduce the number of iterations of the algorithm. The next step is to take each point (vendor evaluations) belonging to this data set and associate it with the nearest centroid. When all the points are connected, the k-number of clusters will be obtained. Next, it is needed to move the centroid to a new position and make a new binding within the resulting clusters. The resulting cycle must be repeated until the centroids $\mathrm{k}$ stop moving during successive iterations.

Thus, the clustering algorithm using $\mathrm{k}$-means is as follows:

1. Select the points $\mathrm{k}$ as the initial centroid (randomly).

2. Repeat the desired number of times, based on the set coefficient $\mathrm{k}$.

3. Form k-clusters by reinforcing each point to the nearest centroid.

4. List the centroid for each cluster.

5. Repeat until the centroids stop moving.

In general, this algorithm aims to minimize the objective function, in this case the error function squared (1). Target function:

$$
J=\sum_{j=1}^{k} \sum_{i=1}^{n}\left\|x_{i}^{(j)}-c_{j}\right\|^{2}
$$

Where, $\mathrm{J}$ is the objective function;

$\mathrm{J}$-goal function;

$\mathrm{k}$ - number of clusters;

$\mathrm{n}$ - number of input points;

$x_{i}^{(j)}-$ certain point $\mathrm{i}$;

$c_{j}$ - centroid for cluster $\mathrm{j}$. 
This algorithm is sensitive to the initial randomly selected cluster centers, but cluster centers can be applied several times to reduce this effect. The main idea of the algorithm is based on an iterative search for a local minimal solution [27]. According to the author's thoughts, the number of iterations can be optimized and reduced due to the taboo search method. This method uses a strategic (general) overview and flexible memory to solve spatial problems [27], where the direction of the vector is important, which depends on its current position and history of change. The method remembers previous decisions and prevents repeating decisions that have already been determined as the worst.

\subsubsection{Taboo search}

The general algorithm for applying taboo search can be described by the following stages [28]:

1. Set input parameters, such as the length of the taboo list, the list of input data, the maximum number of iterations.

2. Determine the optimal starting point (in this case you can use the method of kmeans)

3. According to the selected calculation function (in this case using the method of kmeans) to choose local maxima of pairwise comparison, which are not specified in the tablist.

4. In each iteration of a pairwise comparison of candidates, a taboo list with the worst values is formed and updated.

5. If one of the conditions of termination is met (the length of the taboo list is exceeded, the number of iterations is exceeded) then the optimal solution will be obtained; otherwise the current local maximum is taken as the starting point for the next iteration and the algorithm is repeated from stage 3 .

Taboo search is used to solve a number of problems, such as the salesman problem, the problem of routing to return the goods, the quadratic problem of destination. Thus, according to the author's thoughts, it is promising to use taboo search in combination with the method of k-means to identify the optimal parts/stores/lubricants supplier for maritime company because by using it the searcher will not come back to the solutions, that are already "assigned" as "not optimal" and are added to the Taboo list. Also it might affect the computer applications, that are based on Kohonen's networks (computer implementation of k-clustering) [29].

\section{Conclusions}

Supplier selection it is a complete task with multiple criteria must be taken into account. The article identifies compromise solutions, that according to the author's thoughts, best meet the needs of maritime companies. The proposed approach combines a number of methods to determine the optimal supplier of (a) parts and stores companies or (b) bunkers and lubricators by compilation of existing studies and extension it with sub-criteria that are used to be used in international literature with those are met in Ukrainian science journals and presented by a Ukrainian companies. Thus, in the first stage, multi-criteria analysis helps to select a specific supplier from many conflicting factors by a certain compromise among the available alternatives. In the second stage, if the manufacturer needs to have more than one supplier - the scale that is built according to the results of hierarchical analysis is processed using the method of k-means combined with taboo search. As a result, the evaluated suppliers are clustered on a certain basis, which is provided by the algorithm and respectively, the company is easier to navigate in the resulting list of companies and, if necessary, replace one supplier with another. 
However, the implementation of the proposed approach, to better meet the needs of a particular enterprise, requires the participation of a responsible person / company's management to prioritize criteria and change the number of clusters depending on the specifics, location and experience with the supplier. The proposed approach is aimed mainly at maritime enterprises and can be used by them.

Further research can be direct at testing this approach at the base of particular enterprise, as well as considered in combination with other methods to solve the problem of choosing a supplier for a specific type of maritime enterprises.

\section{References}

1. Bilovodsjka, O. (2018). Ocinjuvannja postachaljnykiv u loghistychnykh (dystrybucijnykh) kanalakh komerciji innovacijnoji produkciji. Marketyngh i menedzhment innovacij, 1, 45-61.

2. Voznjuk, N., Rusynova, O., Parubec, E., Shkolenko, O., Ermyshova, S. (2019). Rozroblennja metodychnogho pidkhodu do upravlinnja postachannjam materialjnogho zabezpechennja u procesi rozvytku promyslovogho pidpryjemstva. Finansovo-kredytna dijaljnistj: problemy teoriji ta praktyky, 1(28), 313-325.

3. Romashhenko, O. (2017). Obghruntuvannja polityky vzajemodiji torghoveljnogho pidpryjemstva iz postachaljnykamy na pidpstavi kompleksnoji ocinky efektyvnosti. Ekonomika. Menedzhment. Biznes, 2(20), 75-82.

4. Kondratjuk, D. (2014). Optymaljnyj postachaljnyk jak chynnyk konkurentospromozhnosti pidpryjemstv. Ekonomika. Upravlinnja. Innovaciji. 1(11).

5. Che, Z., Wang, H. (2010). A hybrid approach for supplier cluster analysis. Computers and Mathematics with Applications, 59, 745-763.

6. Yu, C., Wong, T. (2015). An agent-based negotiation model for supplier selection of multiple products with synergy effect. Expert Systems with Applications, 42, 223-237.

7. Khaleie, S., Fasanghari, M., Tavassoli, E. (2012). Supplier selection using a novel intuitionist fuzzy clustering approach. Applied Soft Compuing, 12, 1741-1754.

8. Gegovska, T., Koker, R, Cakar, T. (2020). Green Supplier Selection Using Fuzzy Multiple-Criteria Decision-Making Methods and Artificial Neural Networks, Computational Intelligence and Neuroscience, 2020, 1-26.

9. Hsu, Y.-C., Lu, H.-A., \& Chu, C.-W. (2015). Evaluating and selecting maritime suppliers. Maritime Policy \& Management, 43(1), 39-58.

10. Ghodsypour, O'Brien (2001). The total cost of logistics in supplier selection, under conditions of multiple sourcing, multiple criteria and capacity constraint. International Journal of Production Economics, 73(1), 15-27.

11. Dulmin, R., Mininno, V. (2003). Suplier selection using a multi-criteria decision aid method. Journal of Purchasing and Supply Management, 9(4), 177-187.

12. Saaty, R. (1987). The analytic hierarchy process: What it is and how it is used. Mathematical Modelling, 9, 3-5, 161-176.

13. Olson, D. (1996). The Analytic Hierarchy Process. Decision Aids for election Problem. Springer Series in Operations Research and Financial Engineering. https://www.springer.com/gp/book/9780387945606

14. Najib, M. (2021). Application of SWOT-AHP to develop organic food marketing strategy. Academy of Strategic Management Journal, 20(1), 1-8.

15. Kunycjka, O., Dzhyghyr, V. (2017). Vykorystannja metodu analitychnoji ijerarkhiji(metodu Saati) dlja vyznachennja miscja roztashuvannja skladsjkogho kompleksu. Naukovo-tekhnichnyj zbirnyk «Visnyk Nacionaljnogho transportnogho universytetu», 1(37), 183-188. 
16. Shukla, M. (2016). Supplier evaluation and selection criteria in business performance of small and medium scale enterprise. International Research Journal of Engineering and Technology, 3(6), 70-76.

17. Ting, S., Cho, D. (2008). An integrated approach for supplier selection and purchasing decision. Supply Chain Management: An International Journal, 13/2, 116-127.

18. Tan, P., Vipin, K. (2005). Cluster Analysis: Basic Concepts and Algorithms. Introduction to Data Mining, 1, 487-568.

19. Rozen, V., Ishhuk, P., Davydenko, L. (2010). Vykorystannja metodu k-serednikh klasternogho analizu pid chas rozvjazannja zadach energhetychnoji bezpeky teoriji. Naukovo-tekhnichnoji biblioteky NU «Ljvivsjka politekhnyka».

20. Chukhraj, A., Vaghyn, E. (2011). Prymenenye metoda k-srednykh dlja formyrovanyja vneshnegho cykla obuchenyja v kompjjuternыkh proghrammakh, obuchajushhykh SQL, 2(50), 81-88.

21. Orlov, P. (2015). Suchasnyj marketyngh: analiz ta perspektyvy rozvytku. Vydannja KhNEU im. S. Kuznecja.

22. Rozhak, J., Salo, A. (2016). Proghramna systema monitorynghu anomaljnoji povedinky bankomativ pry provedenni zlovmysnykh tranzakcij. Suchasnyj stan ta perspektyvy rozvytku komp'juternykh system ta merezh. Materialy konferenciji.

23. Lotosh, O. (2019). Klasternyj analiz seghmentaciji ghaluzi. Visnyk Odesjkogho nacionaljnogho universytetu. Ekonomika, 5(78), 37-42.

24. Liu, W. Luo, T., Wang, W. (2006). Quality evaluation for three textual document clustering algorithms, J. Graduate School. Chinese Acad, 23, 640-646.

25. Kanungo, T., Mount, D., Netanyahu, N. (2002) An Efficient k-means clustering algorithm: Analysis and implementation. IEEE Trans. Pattern Anal. Mach. Intell. 24, 881-892.

26. Susana, A., Leiva-Valdebenito, F., Torres-Aviles. (2010). A Review of the Most Common Partition Algorithms in Cluster Analysis: A Comparative Study. Colombian Journal of Statistics, 33(2), 321-339.

27. Velmurugan, T. (2012). Efficiency of k-means and k-medoids algorithm for cluster Arbitrary Data Points. Int. J. Computer Technology \& Application, 3(5), 1758-1764.

28. Wei, C.-T., Zuo, H., Jiang, C.-B., Li S.-F. (2017). Modeling Multilevel Supplier Selection Problem Based on Weighted-Directed Network and Its Solution, Discrete Dynamics in Nature and Society, 2017, 1-12.

29. Mahadab, A. (2020). A Study of Self- Organizing Maps(SOM) Neural Network Using Matlab. Research on Humanities and Social Sciences, 6(10), 1-22. 